\title{
SECOND SYMPOSIUM ON APPLIED GLACIOLOGY: OPENING COMMENTS
}

\author{
by \\ Colonel Wayne A. Hanson \\ Commander and Director, U.S. Army Cold Regions Research and Engineering Laboratory
}

\begin{abstract}
Good morning, ladies and gentlemen. We at CRREL are particularly honored to host this second Symposium on Applied Glaciology of the International Glaciological Society. Welcome to New Hampshire.

From a personal view point, being from Alaska and having Norwegian blood in my veins makes anything related with ice, snow or frozen ground close to my heart. Judging from the listing of papers, you have an exciting week ahead of you. During the social periods I encourage you to enjoy New Hampshire and experience Yankee food, Yankee ingenuity and Yankee hospitality. CRREL is proud of its contributions to international science, and we are glad you are here so we can not only interact with this very distinguished group, but also show you our facilities during the tour on Wednesday.

Thank you and have a good symposium.
\end{abstract}

